Annals of Warsaw University of Life Sciences - SGGW

Land Reclamation No 41 (2), 2009: 153-166

(Ann. Warsaw Univ. of Life Sciences - SGGW, Land Reclam. 41 (2), 2009)

\title{
Land availability analysis and social attitude aspects in relation to implementation and development of short' rotation forestry systems in Poland
}

\author{
ANNA WRÓBEL ${ }^{1}$, JÓZEF MOSIEJ ${ }^{2}$, MARTIN WEIH ${ }^{3}$ \\ ${ }^{1}$ Institute for Fuels and Renewable Energy, Warsaw, Poland \\ ${ }^{2}$ Department of Environmental Improvements, Warsaw University of Life Sciences - SGGW \\ ${ }^{3}$ Swedish University of Agricultural Sciences, Department of Crop Production Ecology, Uppsala, \\ Sweden
}

\begin{abstract}
Land availability analysis and social attitude aspects in relation to implementation and development of short' rotation forestry systems in Poland. After observations of European development of renewable sources, and according to protocols and directives, set by both European and Polish policy makers, there is a need to find methods to support the future development of Short Rotation Forestry (SRF) using fast-growing trees on agricultural land, and to overcome potential problems. In this paper society attitudes towards future developing options for SRF energy plantations in Poland were investigated. In the investigation, two kinds of questionnaires were presented to various representatives of branches that have a potential interest in the subject. Individual representatives for the groups of industrial and municipal representatives, farmers, researchers and academic teachers, etc. were pooled. The results showed that main difficulties may arise from farmer attitudes towards nontraditional crops. This group of people showed great suspiciousness towards new crops, an attitude, which might be explained in part by the fact that the average level of knowledge concerning SRF energy plantations was low. Another factor that may strongly influence the introduction of SRF plantation is the land availability and suitability. Concerning the relatively large arable lands in Poland in comparison to other European countries the land availability potential has been investigated. On the base of two factors projecting the mentioned aspects of land, the analysis has been performed to figure out regions in Poland with the highest short rotation forestry potential.
\end{abstract}

Key words: biomass, SWOT analysis, land suitability, fallow land, social opinion.

\section{INTRODUCTION}

Due to changing environment as well as current developments in industry and technology there is a great need to achieve in future less dependency on common energy sources and fossil fuels. Poland, as other EU countries, supports a requirement to partly replace the energy gained from traditional fuels by energy originating from alternative sources.

Except for various European directives there were many national bills passed in order to increase the amount of energy from renewable sources e.g. wind, or water-energy plants. Strong attention was paid to the sector of biomass as the one to be the most promising in the future development of renewable energy sources (RES).

Polish industry is mainly based on the use of energy from coal, only in small parts from other sources of energy (gas and crude oil) that results in high dependency on only one energy source, which makes the national economy 
insecure (Wróbel 2007). According to the data from year $2006,49 \%$ of energy in Poland is produced from hard coal, $13 \%$ from brown coal, $31 \%$ together from crude oil and natural gas and only about $6 \%$ comes from renewable sources of energy (GUS 2007).

Due to the size of Polish arable land the most promising renewable source is estimated to be biomass; therefore huge part of efforts should be involved in the development of this branch (Dam et al. 2005, Nilsson et al. 2001). Different kinds of biomass show various properties. For Energetic generation purposes wood, wastes from wood industries, straw, biomass from energy plantations, organic wastes and sludge can be used. The less moisture it is, the better properties according to the usage it shows. Biomass can be processed within different systems, depending on the planned product and use. Direct combustion and producing biogas are the best known methods of transforming biomass into energy. However, there are several modifications and enhancements used within these methods that are commonly used.

Under the conditions in Central Europe, a very promising branch of producing biomass is, according to many scientists, the system of short rotation forestry using fast-growing trees (e.g. poplar, willow) on agricultural land. Especially in Poland, where the total area of arable land is large, the development of SRF systems could possibly yield great results.

Short Rotation Forestry is a system of planting fast-growing-species during short periods of time -2 to 5 years - to receive biomass that can be used to produce energy. Due to the fact that this branch of bio-energy is relatively new in both Europe and in the World there is still a strong need to dissolve many doubts in this sector and improve various aspects concerning productivity (Weih 2009).

Despite the great potential of biomass in Europe there have been some problems detected. Because of the fact that the idea is pretty new, not much information have been spread, especially in the eastern countries, like Poland where RES are still on the low level of development comparing to some other European countries. Farmers and land owners should be mainly involved in the legislations and laws concerning the topic and that should be ensured by using special methods of education and availability and simplicity of performed regulations and directives.

Difficulties in access and understanding regulations connected with bioenergy law may cause discouragement among potential investors, especially due to the fact that during the very last years several new laws and bills have been introduced.

That leads to the social aspect which should be also taken into consideration. Except for scientists who are able to work on technical problems and theoretical doubts connected with the idea of establishing new plantations, there are land owners and farmers that should be convinced and willing to cooperate. Polish farmers may be distrustful towards new concepts, for example changing into different crops production. They may not want to change already existing plantations, which provide profits, into energy plantations that are still economically not secure. It may occur to 
be an obstacle to encourage land owners to grow species that are still not specified according to their environmental conditions and potential financial profits. Farmers need very basic, professional, practical information about how to grow energy crops, what conditions they need, available subsidies, etc (Sinnisov 2006). The problem with lack of knowledge has been often mentioned by several scientists (Sinnisov 2006, Spinelli and Kofman 1996).

About $20 \%$ of the whole population in Poland is employed in agriculture. Good point for starting with development of polish short rotation forestry would be to separate land that is available for energy crops. All the energy species are not highly demanding concerning agroclimatic conditions, however, as all the plants they need particular sites to be grown.

\section{MATERIAL AND METHODS}

\section{Social analysis}

In order to check the attitude and possibilities of short rotation forestry plantations development and introduction two types of questionnaires have been distributed among various individuals connected with the topic. In this research two forms have been used in the pooling process, the internet form of questionnaire $(\mathrm{Q} 1)$ and inquiry form for personal pooling (Q2) Different research units, organizations and companies have been taken into consideration due to the need of checking wide range of possibilities. The questionnaire sent via internet was formed on the base of similar questionnaires used in Sweden.
Both forms of questionnaires aimed at the investigation of attitudes towards the development, possible obstacles and profits from maintaining and progressing non-food agriculture by using SRF.

The attitude towards SRF plantations as well as general knowledge has been included in the questions. More detailed cases, e.g., possible species, size and shape of plantations, and problems that may appear during the management of plantations were investigated.

Due to the fact that this part of research included elements of SWOT analysis, the results from a questionnaire were not possible to be analyzed quantitatively. The qualitative assessment has been made. Results were dissected, under different conditions. Time of spreading questionnaires was taken into account, as well as different groups of recipients and the form of questionnaire.

\section{Land availability and suitability factors}

The total fallow land in Poland, according to the EUROSTAT data reaches the area of $1761 \cdot 1000$ ha which is comparable in the size only to Spain and France so it is possible to assume that fallow land in Poland is large comparing to other European Countries. The reason for such a large fallow land has not been checked carefully and there is no existing data concerning the percentage of wasteland consist in the area of fallow land. The fallow land data is available on the level of voivodeships established in year 1999. By the definition from EUROSTAT, fallow land is land included in the crop rotation system, which is left to recover normally for the duration of a crop year. Fallow land can be used for energy crop 
production, but not for the harvesting of food crops. Fallow land may be (i) bare land bearing no crops at all, (ii) land with spontaneous natural growth, which may be used as feed or ploughed in, (iii) land sown exclusively for the production of green manure (green fallow) .

The amount of fallow land in Poland depends on the analyzed area and varies among different voivodeships (Fig. 1). use due to the amount of fallow land. On the basis of this data there were formed maps of suitability which are shown in the results part.

As the data including amounts of fallow lands for particular voivodeships is available there is no detailed information about the soil suitability is different regions. However, the soil quality classification has been done

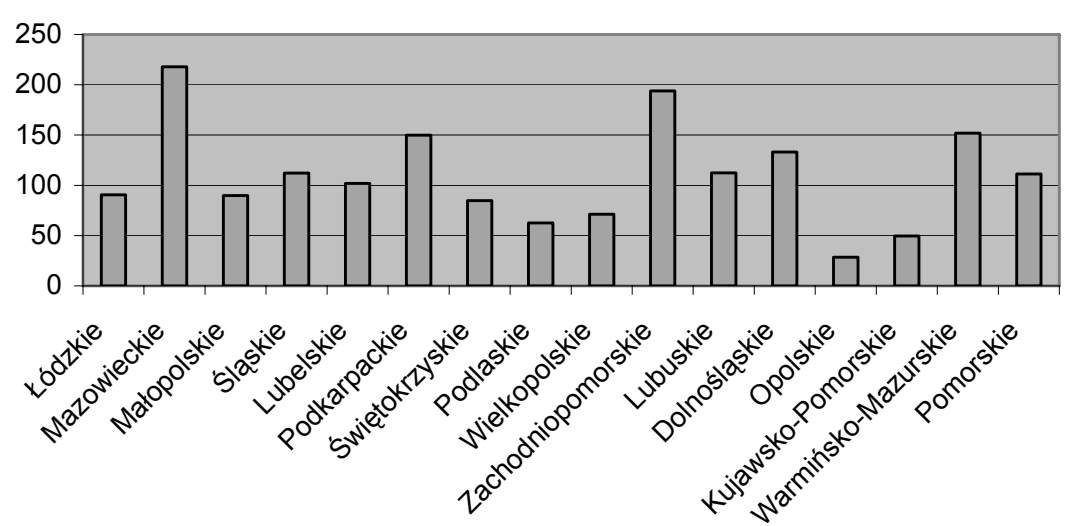

FIGURE 1. Amount of fallow land in particular provinces in Poland (RENEW, 2007, 2008)

The data is available on the level of voivodeships which are shown on the chart above.

Sixteen regions of Poland have been divided into four groups according to the amount of fallow land found in these areas. In each group there were four regions. The amounts of the groups were as follows:

I. 45-75·1000 ha [1p]

II. $76-105 \cdot 1000$ ha $[3 p]$

III. $106-150 \cdot 1000$ ha [5p]

IV. $151-220 \cdot 1000$ ha $[7 \mathrm{p}]$

Depending on the amount of fallow land every group was assigned to a particular number of points, so each voivodeship was given a number of points according to its ability of land for the old provinces division. The Agriculture Land Usefulness Indicator (ALUI) has been set to assess the land suitability. The indicator consists of the total estimation of several factors e.g. agro-climate, water conditions, relief and a soil classification

Forty nine regions formed five groups presenting different levels of the agriculture land usefulness indicator. The assignment of regions to particular groups has been done after (Witek 1994).

I. indicator 40.1-50.0 [1p]

II. indicator 50.1-60.0 [2p]

III. indicator $60.1-70.0$ [3p]

IV. indicator $70.1-80.0[4 \mathrm{p}]$

V. indicator $80.1-90.0[5 \mathrm{p}]$ 
Similarly to the method of fallow land assessment, the groups were given points depending on their suitability for energy crops plantations establishment. The highest amounts of points were assigned to areas performing the highest ALUI. Both maps presenting the division of the regions among groups are in the results part.

Two analyzed suitability factors showed on maps prepared for different province division have been presented on one map as two layers and the points of two analyzed factors were summed up. The method provides possibility for analysis of the data and pointing out the regions with the highest potential and the lowest potential. The aim of this analysis was to put every region in the group according to the points given, while analyzing both factors.

The regions with the highest amount of fallow land and the highest level of the agricultural land usefulness indicator were estimated to have the greatest potential for the development of energy plantation, and in the contrary provinces where the fallow land covers slight amount of land and the ALUI occurred to be low were assigned to class of regions with low potential.

TABLE 1. Evaluation of the land suitability

\begin{tabular}{|c|c|l|}
\hline Class & Amount of points & \multicolumn{1}{|c|}{ Suitability } \\
\hline I & 11 & Very high \\
\hline II & 10 & High \\
\hline III & 9 & Good \\
\hline IV & 8 & Passable \\
\hline V & 7 & Medium \\
\hline VI & 6 & Poor \\
\hline VII & 5 & Acceptable \\
\hline VIII & 4 & Low \\
\hline IX & 3 & Very low \\
\hline
\end{tabular}

On the basis of two analyzed factors nine classes of land suitability have been established (Tab.1). The classes and the total amount of points are shown in the box. According to the calculation two other classes have been distinguished, however, these classes have not appeared on the area of Poland, therefore, were not taken into consideration during the analysis.

\section{RESULTS}

\section{Positive aspects and barrier - forming factors}

Due to the fact that some questionnaires were spread via internet and some were gained personally, the responses were analyzed separately for the two groups.

The general opinion about SRF plantations was positive, except for one answer that came from an energy plant that revealed neutral opinion. The main positive aspects and negative points connected with the introduction and development of SRF plantations in Poland have been listed a table (Tab. 2). Negative points of the analyzed venture have been shown on the basis of weaknesses and threats mentioned by respondents while opportunities and strengths formed a background for positive aspects consideration. All the aspects mentioned by pooled have been divided not only in terms of positive and negative meaning but also due to the branch which they are connected with. According to the results, opportunities and strengths which were brought up are the majority of all mentioned aspects, what is clearly seen in the presented Table 2. 
TABLE 2. Strengths, weaknesses, opportunities and threats listed by responders

\begin{tabular}{|c|c|}
\hline Weaknesses and threats & Opportunities and strengths \\
\hline \multicolumn{2}{|c|}{ Ecological aspects } \\
\hline $\begin{array}{l}\text { - Limitation of biodiversity } \\
\text { - Problems with pests }\end{array}$ & $\begin{array}{l}\text { - Use of worst land classes } \\
\text { - Increase of } \mathrm{CO} 2 \text { absorption } \\
\text { - Decrease of flood-risk } \\
\text { - More control of steppe-formation process } \\
\text { - Increased biodiversity }\end{array}$ \\
\hline \multicolumn{2}{|c|}{ Economy - related aspects } \\
\hline $\begin{array}{l}\text { - High equipment and labour costs } \\
\text { - Poor negotiation position for the price } \\
\text { - High establishment costs } \\
\text { - No income before first harvesting } \\
\text { - Price not competitive to traditional crops } \\
\text { - Instability of the energy market }\end{array}$ & $\begin{array}{l}\text { - Little input of agro-chemicals } \\
\text { - Diversification of activities } \\
\text { - Decrease of failure risk } \\
\text { - Access to favorable credits } \\
\text { - New, independent source of energy } \\
\text { - New work places } \\
\text { - Extra income for the farmers } \\
\text { - Development of related infrastructure }\end{array}$ \\
\hline \multicolumn{2}{|c|}{ Others } \\
\hline & $\begin{array}{l}\text { - Lack of knowledge about energy crops } \\
\text { - Not clear subsidies conditions }\end{array}$ \\
\hline
\end{tabular}

There were also different opinions on the possibilities to increase benefits other than biomass production from energy plantations. The majority of the respondents mentioned that most important factors are the involvement of local communities into the management of plantations, the development of this branch in the future, as well as the necessity to spread information about possible ecological and economic profits from using biomass instead of traditional energy sources.

Among the other suggestions there were, for example, possible profits that may arise from the use of species suitable for phytoremediation, or the advice to use as much traditional cultivation methods as possible. It was also suggested that energy plantations would be more profitable when being used for other purposes, for example as wind barriers or flood protecting areas. It was suggested that using machinery together with other farmers may decrease the costs, which are considered to be quite high (Sinnisov 2006, Nillson et al. 2006).

Questions concerning the estimated knowledge about management of energy crops have been also included in both forms of questionnaires. According to the results half of pooled farmers assess their knowledge as limited, only $6 \%$ claim to be well informed about different aspects connected with the topic. This fact emphasize again the strong lack of knowledge among potential investors (Fig. 2).

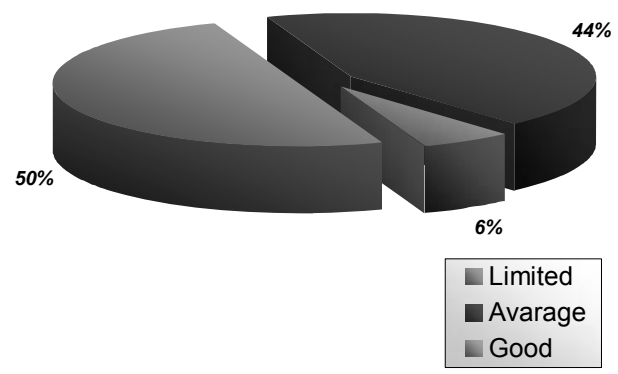

FIGURE 2. Estimated knowledge about energy crops among farmers 


\section{Regions potential}

Despite the reasons for changes in the fallow landamounts among voivodeships, it is possible to assume that if taking into consideration the areas assessed as fallow land, the highest potential for developing SRF systems are in Mazowieckie and Zachodniopomorskie regions, while Warmińsko-Mazurskie and Podkarpackie regions show relatively significant potential. According to the analyzed data the smallest areas can be found in regions Opolskie, Kujawsko-Pomorskie, Podlaskie and Wielkopolskie (Fig. 3).

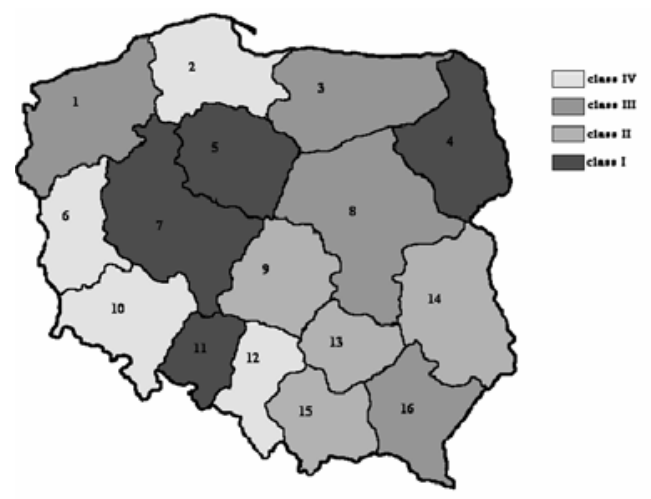

kept to clarify the prospect. This system allows analyzing conditions on the provinces level.

The poorest suitability conditions were found in the provinces: podlaskie, wielkopolskie and Kujawsko-Pomorskie, however, only the Podlaskie voivodeship is completely covered by areas belonging to very low suitability class. The best conditions were found in Podkarpackie region where the dominating class of suitability is very high and the rest of the area is covered by class II. Zachodniopomorskie and Warmińsko-Mazurskie regions show high suitability of the area

\begin{tabular}{|l|}
\hline 1. Zachodniopomorskie \\
2. Pomorskie \\
3. Warmińsko-Mazurskie \\
4. Podlaskie \\
5. Kujawsko-Pomorskie \\
6. Lubuskie \\
7. Wielkopolskie \\
8. Mazowieckie \\
9. Lódzkie \\
10. Dolnośląskie \\
11. Opolskie \\
12. Śląskie \\
13. Siętokrzyskie \\
14. Lubelskie \\
15. Małopolskie \\
16. Podkarbackie \\
\hline
\end{tabular}

FIGURE 3. The classification of provinces according to the amount of fallow land

According to the data, the agriculture land usefulness indicator reached the highest values in the provinces: Zamojskie, Krakowskie, Opolskie and Wrocławskie (Witek 1994). The lowest values of the indicator were found in Kaliskie and Nowosądeckie regions (Fig. 4).

As the data for two factors have been shown on one map, the examination of the conditions was carried out. The results were shown on the map (Fig. 5) where the contour of new provinces is as well, since on the area of these regions only suitability classes I, II and III can be found. Good suitability of the area was also detected in almost half of the Mazowieckie region and eastern part of Dolnośląskie region while the southern part of Małopolskie and eastern part of Opolskie regions occurred to have very low potential.

The rest of the regions have various conditions. It was difficult to assess the correlation between the location of the analyzed regions and the level of potential 


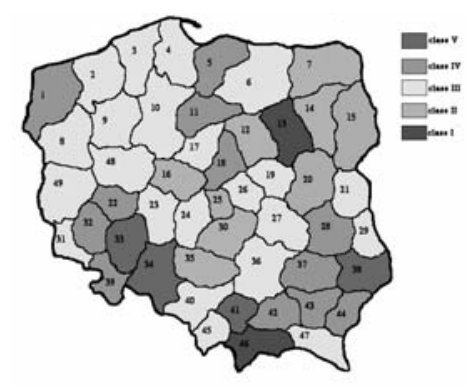

\begin{tabular}{|lll|}
\hline 1. Szczecińskie & 2. Koszalińskie & 3. Słupskie \\
4. Gdańskie & 5. Elbląskie & 6. Olsztyńskie \\
7. Suwalskie & 8. Gorzowskie & 9. Pilskie \\
10. Bydgoskie & 11. Toruńskie & 12. Ciechanowskie \\
13. Ostrołęckie & 14. Lomżyńskie & 15. Białostockie \\
16. Konińskie & 17. Włocławskie & 18. Płockie \\
19. Stoł. Warszawskie & 20. Siedleckie & 21. Bielskopodlaskie \\
22. Leszczyńskie & 23. Kaliskie & 24. Sieradzkie \\
25. Miejskie Łódzkie & 26. Skierniewickie & 27. Radomskie \\
28. Lubelskie & 29. Chełmskie & 30. Piotrowskie \\
31. Jeleniogórskie & 32. Legnickie & 33. Wrocławskie \\
34. Opolskie & 35. Częstochowskie & 36. Kieleckie \\
37. Tarnobrzeskie & 38. Zamojskie & 39. Wałbrzyskie \\
40. Katowickie & 41. Krakowskie & 42. Tarnowskie \\
43. Rzeszowskie & 44. Przemyskie & 45. Bielskie \\
46. Nowosądeckie & 47. Krośnieńskie & 48. Poznańskie \\
& & 49. Zielonogórskie \\
\hline
\end{tabular}

FIGURE 4. Classification of the provinces according to the ALUI

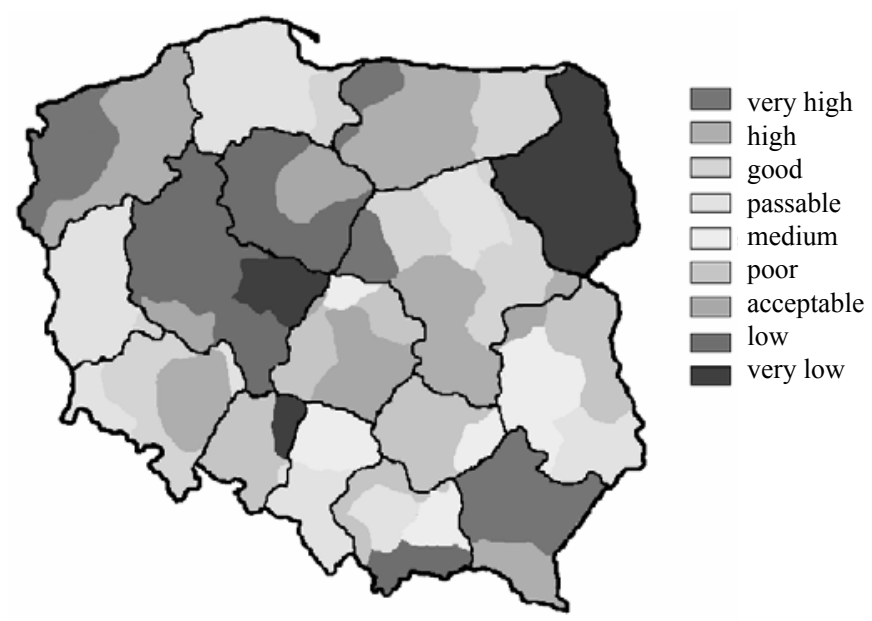

FIGURE 5. Land suitability map for SRF system

estimated in these regions mainly due to the fact of presumable influence of other factors. The division of suitability classes is shown on the map (Fig. 5).

\section{DISCUSSION}

The general potential of short rotation forestry plantations development in Poland can be assessed as good (Ericsson et al. 2006, Sinnisov 2006). The land analysis showed that in the area of Poland there are places where plantations can be successfully located. However, both analyzed factors - the fallow land and the agriculture land suitability indicator need to be discussed.

There are two factors that may explain the fallow land location. It is known that north-western regions have the richest soils that provide the highest productivity. These Regions are assumed to be well financially situated mainly due to the high level of industrial development. These factors are likely to cause the high necessity of land use and as a consequence smaller areas of 
fallow land left. However, the financial factor can be understood from a different position in Podlaskie and Świętokrzyskie regions that are rather financially poor regions in Poland. It is possible to assume that in mentioned regions the land productivity is much lower and any part of land is used to support farmers and their families.

The fallow land may be used for different purposes, not only agricultural. Sometimes the discussed area is involved into landscape planning enlarging of cities, towns etc. as well as for the development of new or already existing industrial areas. In this study the total area of fallow land is taken into consideration and assumed to be suitable for energy crops development.

The data considering the ALUI was available only on the level from year 1994 which can influence the reliability of the analysis. The indicator calculated for particular regions could have changed, however, it is not predicted that the mentioned indicator can change significantly during ten years. It is important to notice that the indicator has been calculated partly on the base of land suitability to different crops. The crops that were taken into consideration were mainly cereals and industrial crops but not the energy species so the values of indicator could differ when estimating the conditions for energy crops.

The results from this part of the project was to point out the areas where the establishment of SRF plantations may be the most successful, however, there are some other factors that may influence the establishment of new plantations.

It is important to notice the significance of choosing the right species for planting. In the USA species that occurred to be the most suitable from various points of view was swichgrass; however, both the species and the clone shall be matched with local agro-climatic conditions, financial background and the knowledge and experience (De la Torre Ugarte 2000). The energy species that is known the best in Poland is willow (Salix sp.) and it is possible to assume that most of the available land that will be used for growing energy species will be covered by willow. As mentioned before, willow stands for the highest percent of already existing energy plantations in Poland and in Europe what results in the widest European experience, both technical and scientific about this plant. Due to these assumptions some other factors should be checked. Willow needs particular agro-climatic conditions and as the establishment of these species plantations is the most likely, some more data should be available within this topic (Stelmach et al. 2008).

In the assessment the individual attitude towards planting new species should be considered. It should be noted that even if the conditions and the land suitability was assessed to be high the owner of the land may not be convinced. The potential negative point of view may be explained by many factors.

Another factorthat shouldbediscussed briefly is the location of plantations regarding the potential demand. As the renewable sources of energy are assumed to have the best results in the domestic use system the particular district heating systems should be considered. If the development was targeted at the small receivers the efforts should be focused on the smooth delivery and operation of the 
system. While the receiver is expected to be a huge energy plant the transportation and storage shall be well organized. It is known that profitability of using biomass as a source of energy is ensured by the distance from the collection place to the conversion place should not exceed estimated distance which was assumed to be about $50 \mathrm{~km}$ radius (Boyd 2000). The distance, in this point of view may form an obstacle for the development of renewable energy sources (Stelmach et al. 2008).

It is important to mention that the timing and method of spreading the questionnaires might have had a significant impact on the number of responses. Personal polling was done during June and September and revealed very good results, because more than $80 \%$ of the inquired persons decided to answer the questions. Questionnaires sent via internet revealed much poorer results. Thus, less than $6 \%$ of the persons contacted by internet responded to the questionnaire. Two factors might have had a strong influence on the frequency of answers. First, the timing during the season of summer vacation might have decreased the number of answers.

The form of the questionnaire might have been another important factor that influenced the result. Open-form questions require some knowledge and take more time to answer than a fixed test form, although this kind of form leaves more possibilities for the receiver to include the desired amount of information.

Three answers were received from persons that claimed not to have time to answer the questionnaire. Many respondents' attitude towards filling in questionnaires was probably negative due to the subject (regarded as uninteresting) and the amount of answers required. In addition, peoplemayhave been suspicious towards filling in a form connected to a project that they never have heard of, although all the necessary information regarding the general background of the project, project partners and objectives were supplied.

It is worth mentioning that the general opinion about the availability of knowledge and information regarding the possibilities For the development of energy plantations was regarded to be poor. According to the national statistics there are currently only a few test plantations of willow established by the energy producer where the growth of Swedish cuttings is tested under Polish conditions (Sinnisov 2006). After the respondents' opinions the targeted result has not been reached. Only among scientists and academic teachers the problem with availability of information has not been mentioned. Farmers need very basic, professional, practical information about how to grow energy crops, the conditions they need, available subsidies, etc (Sinnisov 2006). The problem with lack of knowledge has been mentioned often by several scientists, (Ericsson et al. 2005, Nilson et al. 2001, Sinnisov 2006). It is believed that energy crops cannot compete with food crops for arable land and since there is no currently set-aside obligation in Poland, these crops do not have many advantages from this perspective. It was observed that Polish farmers base their decisions simply on what enables them to support their family. It was noticed that farmers commonly engage in any 
business that promises maximum profit, assuming that agro climatic conditions are in favor. Since farmers have so far not seen profitable examples of energy crop enterprises in Poland in practice, they are rather cautious towards growing them (Sinnisov 2006). This can be related to the cautious nature of Polish farmers and other barriers explained elsewhere (Sinnisov 2006).

The interesting point of analysis concerns the farmers' willingness to start energy plantation from the age point of view. According to the Swedish experience farmers in the average age of fifty are more interested in planting energy species, while in Poland this interest decrease with the age (Rosenqvist et al. 2004, Roos and Rosenqvist 2000).

The results from the questionnaire may be used by Polish decision-makers to reconsider the availability of practical information to the public and the need of raising interest of renewable energy branch among different groups of people with a potential interest in, or impact on, the subject of renewable energy.

Only agricultural land that is not needed for food and feed production is considered to be available for the production of energy crops (Dam et al. 2005). However, there is a lack of information concerning the practical amount of land available for energy crops/surplus land in many European countries.

The obstacle with establishing SRF plantations may be connected with the mean farm size in Poland. As it was assessed the profitability of growing energy species is strongly connected with the size, the relatively small Polish farms may occur to be less profitable in the frame of planting energy species.
Finally, not many studies combine cost levels with a biomass potential study. However, this is - as also mentioned - an important barrier (or driver) for further development of biomass production. Some new-established European laws were supposed to make it easier for potentialdevelopersto investinrenewable sources of energy. The majority of the interviewed farmers stated that they have not engaged in energy crop cultivation so far because it is not profitable compared to other crops under current conditions (Sinnisov 2006) .

According to this investigation, it is possible to assume that the need to introduce alternative sources of energy into Polish national economy is well-known and understood by all the polled. It is very important to ensure the acceptance of community towards new legislation and changing laws, however, sometimes difficulties may occur.

According to the fact that Poland has joined the EU not long time ago, it is a good sign that Polish stakeholders from different branches showed an interest in the development of new energy sources. However, the main difficulty to overcome may be the fact that the interest is not supported by the good intention to get involved in the development, which can be concluded from the very low amount of responses received.

During the last years there have been new directives established both in the EU and Poland. For example, in 2000 the Polish Parliament adopted a document entitled "Development Strategy of Renewable Energy Sector", which calls for a $7.5 \%$ contribution of SRF plantations in the primary energy supply by 2010 and a $14 \%$ contribution by 
2020 (Ericsson et al. 2005). Due to these requirements it is necessary for Poland to improve the systems for gaining energy from renewable sources.

Agriculture is an important sector in Poland. Although its share of the GDP has declined steadily during the past $10-15$ years (from $9 \%$ in 1990 to $4 \%$ in 2006), it still employs about $18 \%$ of the working population in Poland (Grzelak 2008). This is more than four times as much as the mean for Europe (Ericsson et al. 2005). The great importance of the agricultural sector in Poland provides significant possibilities to develop the field of biomass production on agricultural land, which already is assumed to be the most promising branch of renewable sources in Poland.

\section{CONCLUSIONS}

The future developments in land use as well as cost and productivity levels in the central European countries are difficult to predict. Some expectations can be extrapolated from the experience made in other European countries, such as the observed rationalization of agriculture in many countries of the EU and increases in land prices and labor costs (Dam et al. 2005). Substituting biomass for fossil fuels in the generation of energy is an important strategy for Poland and the EU in order to mitigate climate change and enhance security of energy supply. The research done within this study pointed out the regions of Poland with the highest potential for the development of SRF systems. Therefore, the future progress in this branch shall be focused on those areas. The social part of research provided knowledge about major barriers for the introduction of SRF systems according to the representatives of society involved into this branch. The obstacles occurred to be mainly economical, what shall be used for future improvement and facilitation of economical and policy aspects which are to support the development of renewable sources of energy.

\section{REFERENCES}

BOYD J., CHRISTERSSON L., DINKELBACH L. 2000: Energy from willow. SAC, The Scottish Agricultural College, Edinburgh, UK.

DAM J. VAN, FAAIJ A.P.C., LEWANDOWSKI I., FISCHER G. 2005: Biomass Production Potentials in Central and Eastern Europe under different Scenarios. Copernicus Institute for Sustainable Development, Utrecht University, The Netherlands and International Institute for Applied Systems Analysis (IIASA) Laxenburg, Austria,

DE LA TORRE UGARTE D. WALSH M., SHAPOURI H., SLINSKY S. 2000: The economic impacts of bioenergy crop production on U.S. Agriculture, University of Tennessee, USA.

ERICSSON K., ROSENQVIST H., GANKO E., PISAREK M., NILSSON L. 2005: An agro-economic analysis of willow cultivation in Poland. Lund Institute of Technology, Sweden and EC Baltic Renewable Energy Centre (ECBREC), Institute for Building, Mechanization and Electrification of Agriculture, Warsaw, Poland.

GRZELAK A. 2008: Znaczenie rolnictwa dla kształtowania sytuacji gospodarczej w kraju. Wybrane problemy na podstawie doświadczeńPolskipo 1990 [Themeaning of agriculture for formation of economic situation in the country. Selected problems 
base on Polish experiences after 1990] Roczniki Naukowe SERiA, tom X, z. 1, 107-112 [Engl. summ.].

GUS, 2007: Rocznik statystyczny rolnictwa i obszarów wiejskich [Statistical yearbook of agriculture and rural areasl] Warszawa [Engl. summ.].

NILLSON H., MCCORMICK K., GANKO E., SINNISOV L. 2006: Barriers to energy crops in Poland - from the farmers perspective, International Institute for Industrial Environmental Economics, Lund University, Sweden and ECBREC Baltic Renewable Energy Centre, Warsaw.

NILSSON L.J., PISAREK M. , BURIAK J., ONISZK-POPLAWSKA A., BUCKO P., ERICSSON K., JAWORSKI L. 2001: Energy policy and the role of bioenergy in Poland. Lund Institute of Technology, Lund, Sweden and EC Baltic Renewable Energy Center (ECBREC) Institute for Building, Mechanization and Electrification of Agriculture, Warsaw, Poland and Technical University of Gdańsk, Gdańsk, Poland,

RENEW, 2006: Renewable Fuels for advanced power-trains. Integrated project, Sustainable energy systems, Deliverable D5.01.03. Residue Biomass potential inventory results 2006, Project coordinated by VOLKSWAGEN AG, ECBREC, Baltic renewable Energy Centre, Institute for fuels and renewable energy, Warsaw, Poland.

RENEW, 2007: Renewable Fuels for advanced power-trains. Integrated project, Sustainable energy systems, Deliverable 5.1.7. Energy crops potentials inventory results, Project coordinated by VOLKSWAGEN AG, ECBREC, Baltic renewable Energy Centre, Institute for fuels and renewable energy, Warsaw, Poland.

ROOS A., ROSENQVIST H. 2000: Experiences of commercial energy crop production - a study of willow growers in Sweden, Swedish University of Agricultural Sciences, Uppsala, Sweden.
ROSENQVIST H., ROOS A., LING E., HEKTOR B. 1999: Willow growers in Sweden, Swedish University of Agricultural Sciences, Uppsala, Sweden. SINNISOV L. 2006: Barriers to dedicated Energy crop cultivation in Poland. MSc Thesis, Lund, Sweden.

SPINELLI R., KOFMAN P. 1996: A review of short-rotation forestry harvesting in Europe.In: Bryce J. Stokes [Ed]: The First Conference of the Short Rotation Woody Crops Operations Working Group, Paducah, KY,USA September 23-25.

STELMACH J., KARCZMARCZYK A., MOSIEJ J. 2008: Wybór obszarów dla upraw roślin energetycznych na terenie powiatu ciechanowskiego. [Selection of the suitable areas for energy crops production in the Ciechanów poviat.] ZP PNR z. 532, 265-274 [Engl. summ.].

WEIH M. 2009: Willow short rotation coppice commercially grown on agricultural land in Sweden - possibilities for improvement of biodeversity and landscape design. IEA Bioenergy, Tosk 30, Technical Review No 4.

WITEK T. (red.) 1994: Waloryzacja rolniczej przestrzeni produkcyjnej Polski według gmin [Valorization of the agricultural area in Poland on the basis of commune level], IUNG, Puławy, Poland.

WRÓBEL A. 2007: Analysis on potential development of Short Rotation Forestry with emphasis on the society attitude under Polish conditions. In: Conference materials: Environmental and landscape aspects in short rotation forestry on agricultural land: a Nordic perspective, Uppsala, Sweden.

Streszczenie: Uwarunkowania spoleczne, gospodarcze $i$ środowiskowe rozwoju plantacji energetycznych $w$ Polsce. Potencjał rozwoju upraw roślin energetycznych został oceniony na podstawie dwóch czynników - dostępności gruntów pod uprawy energetyczne oraz opinii społecznej na temat rozwoju plantacji energetycznych na terenie Polski. Przy ocenie dostępności gruntów wzięto pod uwagę całkowitą powierzchnię terenów 
odłogowanych i ugorów, jako rejony potencjalnie odpowiednie pod uprawę roślin energetycznych, oraz wskaźnik jakości rolniczej przestrzeni produkcyjnej określony w 1994 roku przez IUNG. Bardzo ważnym zagadnieniem jest odpowiedni dobór gatunków do warunków agroklimatycznych panujących w danym regionie. Wierzba wiciowa jest gatunkiem najczęściej uprawianym w Europie. Posiadamy największą liczbę danych i wyników badań dla tego gatunku, a rezultaty uprawy są najbardziej obiecujące. Polskie warunki agroklimatyczne sprzyjają rozwojowi tej rośliny. $\mathrm{Z}$ tych powodów wierzba wiciowa sugerowana jest jako gatunek najwłaściwszy dla rozwoju plantacji energetycznych w Polsce. Analiza nastawienia społecznego została wykonana na podstawie odpowiedzi z ankiet uzyskanych od przedstawicieli władz lokalnych, środowiska akademickiego, prywatnych spółek związanych z uprawą roślin energetycznych itp. Pod uprawę roślin energetycznych dostępne mogą być tylko takie tereny, które nie są potrzebne pod produkcję żywności oraz nie stanowią ważnego punktu w planach zagospodarowania terenu. Aspekt konkurencji z produkcją żywności ma znaczenie ekonomiczne, głównie w kwestii eksportu zbóż do krajów poza Europa, i powinien być brany pod uwagę przy podejmowaniu decyzji co do rozpoczynania upraw energetycznych. Zagadnienie wprowadzania i rozwoju w Polsce upraw energetycznych wymaga jeszcze wielu różnorodnych studiów i opracowań. Powinny one dotyczyć szczególnie warunków i metod upraw, jak i zagadnień ekonomicznoprawnych dotyczących całości zagadnienia. Szczególnie te ostatnie budzą najwięcej wątpliwości u ankietowanych. Określone w pracy regiony o najlepszych warunkach upraw energetycznych oraz wiele udogodnień, w tym ekonomicznych, powinno zaowocować szybkim rozwojem dziedziny, co w dalszej perspektywie przysłuży się głównemu celowi energetyki odnawialnej, jakim jest ochrona środowiska przyrodniczego. Wykazany w pracy potencjał Polski powinien być w tym kierunku wykorzystany, dając jednocześnie możliwość zagospodarowania wielu nieużytków i wykorzystania przez rolników środków finansowych na rozwój odnawialnych źródeł energii.

MS. received December 2009
Author's address:
Anna Wróbel
Instytut Paliw i Energii Odnawialnej ul. Jagiellońska 55, 03-301 Warszawa e-mail: awrobel@ipieo.pl 